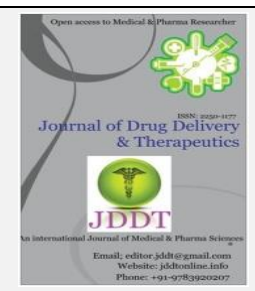

Research Article

\title{
Synthesis and Biological Evaluation of Novel Schiff Bases of Aryloxy Moiety
}

\author{
Purushottam R. Laddha*, Kailash R. Biyani
}

Department of Pharmaceutical Chemistry, Anuradha College of Pharmacy, Chikhli. Dist. Buldhana, Maharashtra, India, 443201

\begin{abstract}
Schiff's bases are condensation products of primary amines with carbonyl compounds. Schiff bases (imines) possess wide variety of biological activities that include antibacterial and antifungal activity. In present work, Schiff bases from 3,5-Dimethoxyphenol (aryloxy moiety) as starting material synthesized. Esterification of 3,5- Dimethoxyphenol led to formation of (3,5-Dimethoxy-phenoxy)-acetic acid ethyl ester (1). (3,5Dimethoxy-phenoxy)-acetic acid hydrazide (2) is derived from Compound (1) by hydrazination. Compound (2) was reacted with different aromatic aldehydes to yield novel imines or Schiff bases (3A-I). The newly synthesized compounds were characterized on the basis of spectral studies and evaluated for antibacterial and antifungal activities. All the synthesized compounds had shown antibacterial and antifungal activity. Schiff bases 3C, 3D, 3E and 3I had shown good antimicrobial activity among all newly synthesized compounds.
\end{abstract}

Keywords: Schiff base, aryloxy moiety, imines

Article Info: Received 12 July 2019; Review Completed 18 Aug 2019; $\quad$ Accepted 22 Aug 2019; Available online 15 Oct 2019

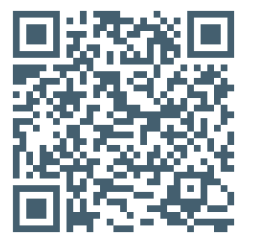

Cite this article as:

Laddha PR, Biyani KR, Synthesis and Biological Evaluation of Novel Schiff Bases of Aryloxy Moiety, Journal of Drug Delivery and Therapeutics. 2019; 9(5-s):44-49 http://dx.doi.org/10.22270/jddt.v9i5-s.3635

*Address for Correspondence:

Purushottam R. Laddha, Assistant Professor, Department of Pharmaceutical Chemistry, Anuradha College of pharmacy,

Chikhli Dist- Buldhana

\section{INTRODUCTION}

The incidence of fungal and bacterial infections has increased dramatically in recent years [1]. Infection is a major category of human disease and skilled management of antimicrobial drugs is of the first importance. The accomplishment of antimicrobial agents, ranging from direct killing of invading pathogens to immune response modulation and other complex biological responses, has stimulated research and clinical interest for more than two decades. However the area is still flourishing due to emerging discoveries in the functions, roles and regulation of antimicrobial agents [2]. Schiff's bases are an important class of organic compounds [3]. They were first reported by Hugo Schiff in 1864 [4] Structurally, a Schiff's base (also known as imine or azomethine) is a nitrogen analogue of an aldehyde or ketone in which the carbonyl group $(>C=0)$ is replaced by an imine or azomethine group. Schiff's bases have also been shown to exhibit a broad range of biological activities, including antifungal, antibacterial, antimalarial, antiproliferative, antiinflammatory, antiviral, and antipyretic properties $[5,6]$. Imine or azomethine groups are present in various natural, naturally derived, and non-natural compounds. The imine group present in such compounds has been shown to be critical to their biological activities [7-10]. Kumar A et al. synthesized a series of Schiff bases of diphenylamine derivatives and evaluated in vitro for their antibacterial activity against pathogenic both Gram-positive bacteria $B$. subtilis and Gram-negative bacteria E. coli [11]. Azab ME et al. combined phthalazinones with 4-methoxybenzaldehyde to yield novel Schiff bases and tested against Bacillus subtilis and Staphylococcus aureus as Gram-positive bacteria, Escherichia coli and Pseudomonas aurignosa as Gramnegative bacteria, and Candida albicans and Aspergillus niger as fungi strains [12]. Sharif HMA et al. reported synthesis and spectral data of eight Schiff bases of salicylaldehyde with different amines, and evaluation of their anti-microbial activities against different bacterial strains. All the bases showed moderate to good activities against all the tested microorganisms [13]. Schiff bases of p-bromo-m-cresol were reported by Fuloria NK et al. The newly synthesized compounds were characterized on the basis of spectral studies and evaluated for antibacterial and antifungal activities [14]. It is clear from the literature review \& market demand, that Schiff bases (imines) possesses wide variety of biological activities like antimicrobial, antitubercular, antimalarial and antiviral. Among various biological activities of several Schiff bases molecules synthesized in literature, the antimicrobial activity was found to be very prominent. According to literature it was also known that Esters, Hydrazides and Imines can be synthesized from different moieties. So, in the view of medicinal importance and synthetic routes to Schiff bases, it was thought worthwhile to study and synthesize compounds possessing 
imino group. It was pertinent to investigate their structural modification. Hence the aim of present study was to synthesize and evaluate antimicrobial activity of Schiff bases of aryloxy Moiety.

\section{EXPERIMENTAL}

Melting points of newly synthesized compounds were determined in open capillary tubes. IR spectra were recorded (in $\mathrm{KBr}$ ) on Schimadzu FTIR Spectrophotometer, ${ }^{1} \mathrm{H}$ NMR spectra on BRUKER Avance-II $400 \mathrm{MHz}$ instrument using $\mathrm{CDCl}_{3}$ solvent and mass spectra on LCMS 2010 EV SHIMADZU Mass spectrometer.

2.1 Ethyl aryloxy acetate (1): A mixture of aryloxy compound $(0.1 \mathrm{~mol})$, ethylchloro acetate $(0.1 \mathrm{~mol})$ and anhydrous potassium carbonate $(0.15 \mathrm{~mol})$ in dried acetone was refluxed for $24 \mathrm{~h}$. Resultant mixture was distilled off and poured on to ice-cold water and stirred. Residue was extracted with ether and the extract was dried over anhydrous sodium sulphate and was purified under reduced pressure to yield compound 1; yield (62.74\%), b.p. (3050 ${ }^{\circ}$ ), IR $1745 \mathrm{C}=0$ of ester, 1149 for C-O of ester.

2.2 Acetohydrazide (2): A mixture of compound 1 $(0.05 \mathrm{~mol})$ and hydrazine hydrate $(0.075 \mathrm{~mol})$ in ethanol was refluxed for $8 \mathrm{~h}$ and after distilling off the solvent the residue was recrystallized from methanol to yield compound 2; yield (70.00\%), m.p. (1340), IR 3306, 3198 for $\mathrm{N}-\mathrm{H}$ and $\mathrm{NH}_{2}, 1674$ for $\mathrm{C}=\mathrm{O}$ of amide, 1524 for $\mathrm{N}-\mathrm{H}$ bending of amide, 1250 and 1065 for C-O of phenyl ether.

2.3 Schiff bases (3A-I): A mixture of compound 2 (0.001 $\mathrm{mol})$ and aromatic aldehyde $(0.001 \mathrm{~mol})$ was refluxed for $8 \mathrm{~h}$ using ethanol and glacial acetic acid. Crystals formed were washed with ice-cold water, dried and recrystallized from methanol to yield compounds $\mathbf{3 A}-\mathbf{I}[15,16]$.

2.4 Screening for biological activity: The synthesized compounds 3A-I were screened for antibacterial activity using Staphylococcus aureus (MTCC 737), Escherichia coli (MTCC 452) and antifungal activity using Candida albicans (MTCC 227) by disk diffusion method at a concentration of 2 $\mathrm{mg} / \mathrm{mL}$ using DMF as solvent. Ampicillin $1 \mathrm{mg} / \mathrm{mL}$ and fluconazole $2.5 \mathrm{mg} / \mathrm{mL}$ were used as standards [17]. The results were recorded using ampicillin and fluconazole as standards are given in Table-4.

\section{RESULTS AND DISCUSSION}

The synthetic route is outlined in Scheme-I. (3,5-Dimethoxyphenoxy)-acetic acid ethyl ester (1) was synthesized by refluxing 3,5-Dimethoxyphenol with ethylchloroacetate in dry acetone. Compound $\mathbf{1}$ on reacting with hydrazine hydrate gave (3,5-Dimethoxy-phenoxy)-acetic acid hydrazide (2). Condensation of $\mathbf{2}$ with various aromatic aldehydes afforded the potent antibacterial and antifungal Schiff bases (3A-I). Physical data of 3A-I are given in Table-1. The structures of all compounds were characterized by spectral analysis. All the synthesized compounds 3A-I had shown antibacterial and antifungal activity to certain extent. From the compounds synthesized, compounds 3C, 3D, 3E and 3I had shown good antibacterial and antifungal activity and the remaining compounds have shown moderate activity on tested organisms (Table-4).

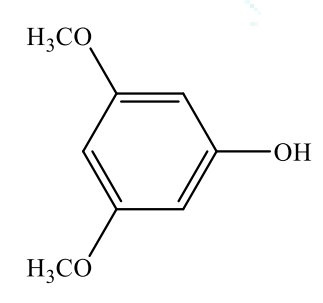

3,5-Dimethoxy-phenol

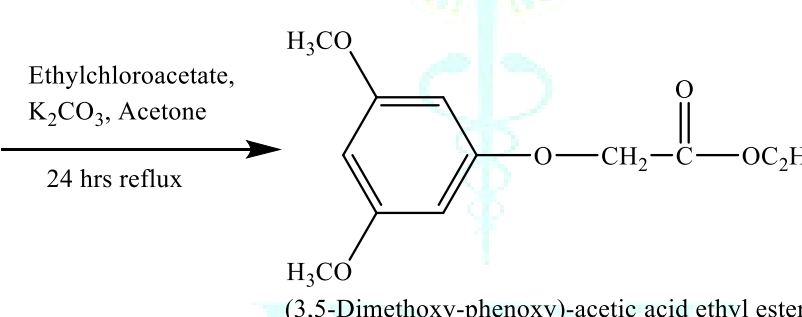

(3,5-Dimethoxy-phenoxy)-acetic acid ethyl ester (1)

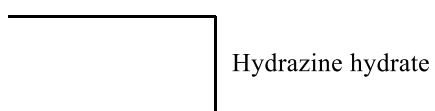

$8 \mathrm{hr}$ reflux<smiles></smiles>

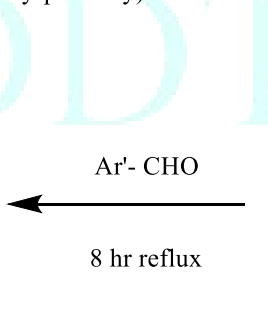

$\mathrm{H}_{3} \mathrm{CO}$

where $\mathrm{Ar}-\mathrm{CHO}=$ aromatic \& heterocyclic aldehydes

\section{Scheme - I: Conversion of aryloxy moiety into Schiff bases}

First of all nucleophilic substitution reaction take place between 3,5-Dimethoxyphenol and ethylchloroacetate in the basic medium to produce the corresponding ethyl ester (1). 


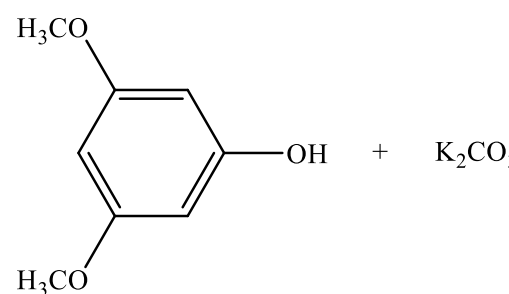

3,5-Dimethyl-phenol
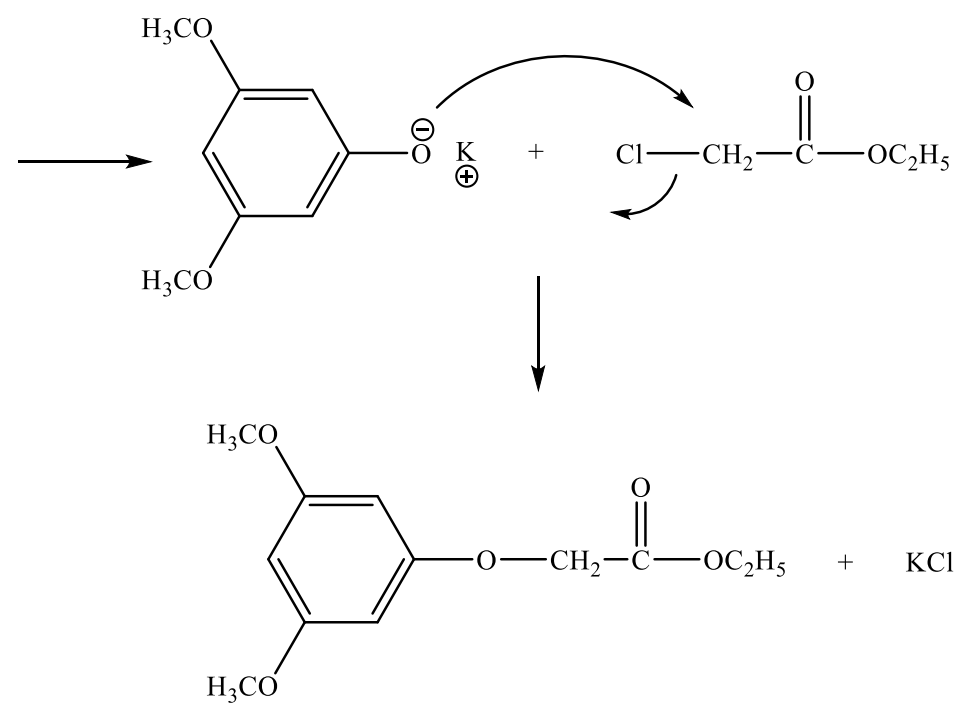

(3,5-Dimethoxy-phenoxy)-acetic acid ethyl ester (1)

The second step involves the synthesis of acid hydrazide through the reaction between hydrazine and the ethyl ester (1). The reaction proceeds by nucleophilic substitution of hydrazine to the ethyl ester carbonyl group to give the corresponding hydrazide (2).

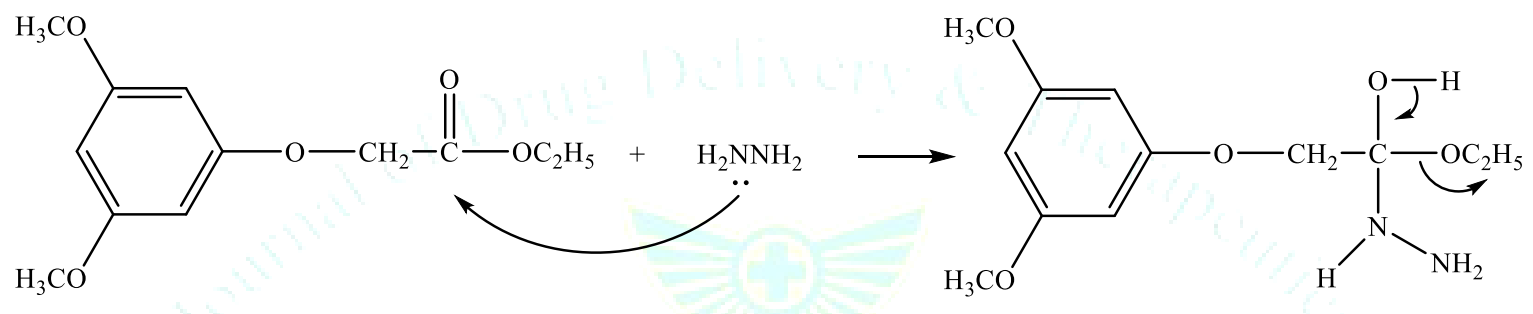

(3,5-Dimethoxy-phenoxy)-acetic acid ethyl ester (1)

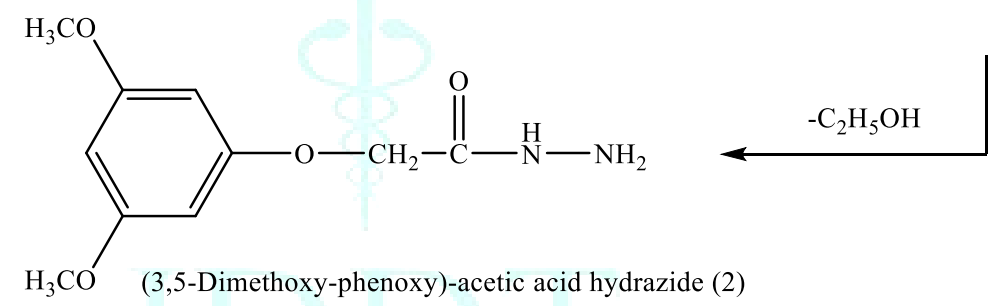

The final step involves nucleophilic attack by the basic nitrogen compound on carbonyl carbon. Protonation of carbonyl oxygen in presence of acid makes carbonyl carbon more susceptible to nucleophilic attack. The addition product undergoes dehydration to produce Schiff bases (3A-I).<smiles>COc1cc(OC)cc(OCC(=O)NN)c1</smiles>

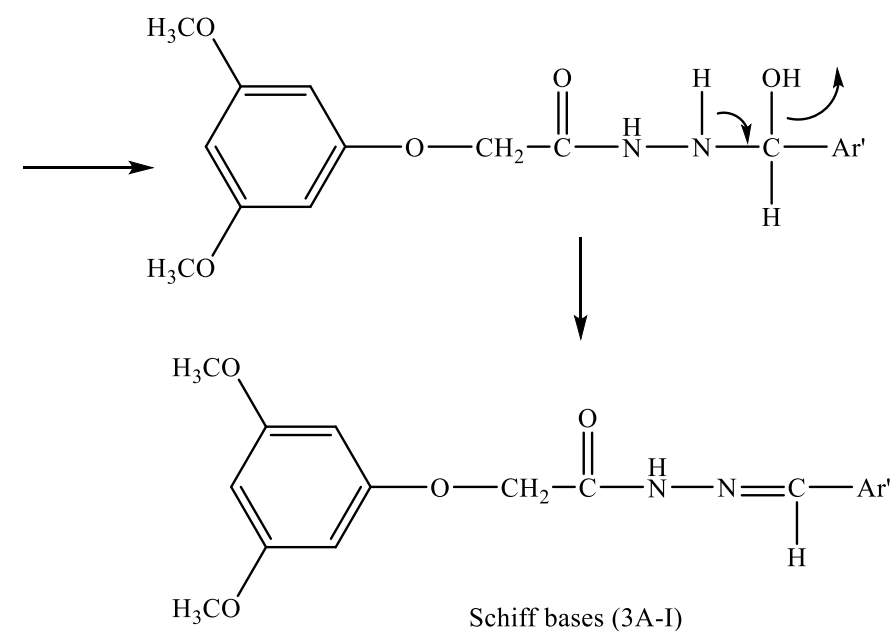


Table - 1: Physical characteristics of synthesized compounds 3A-I

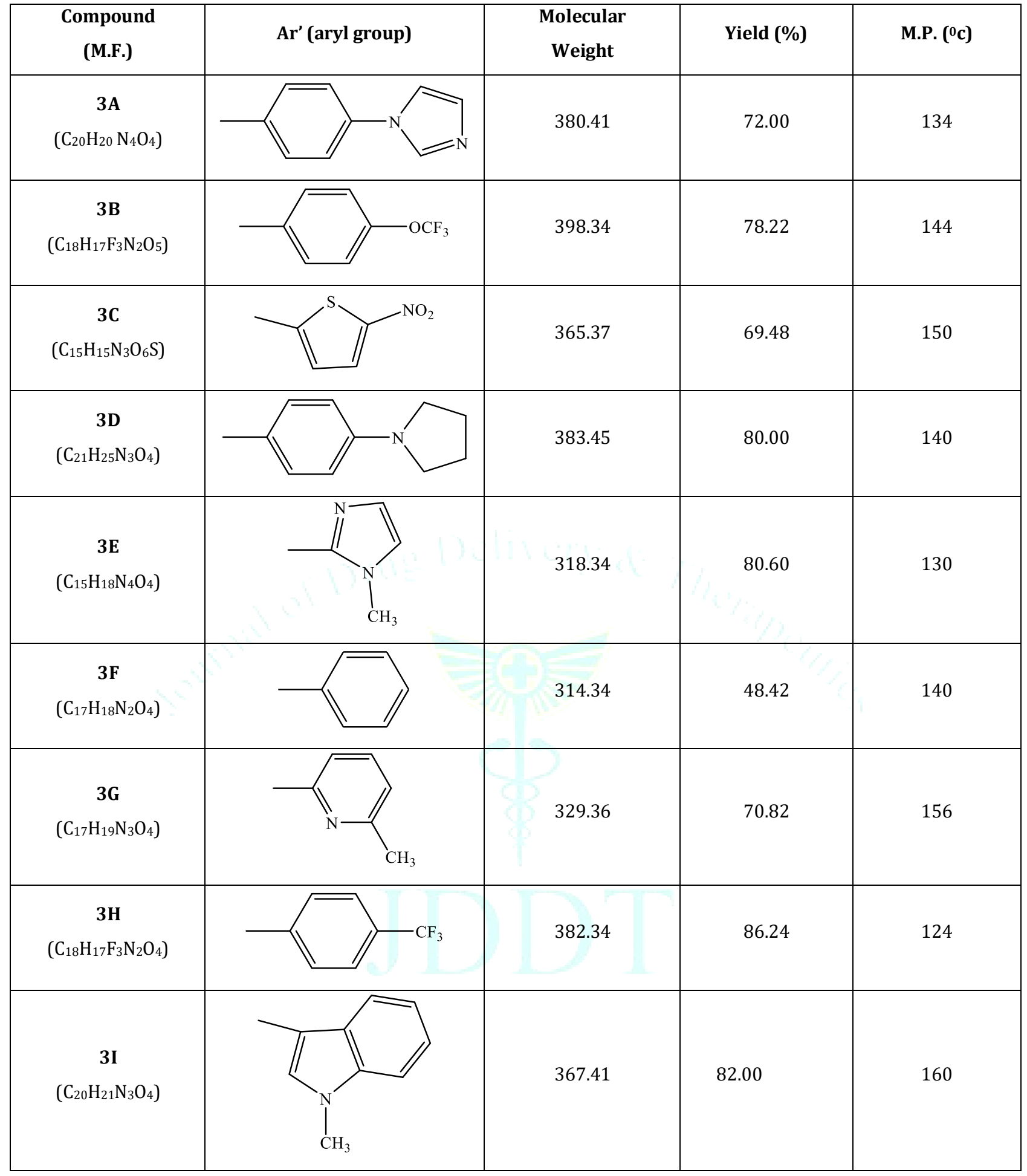


Table 2: Mass and 1H-NMR data of 3A-3I

\begin{tabular}{|c|c|c|}
\hline Compd. & Mass (M/Z) & 1H-NMR (ppm) \\
\hline $3 \mathrm{~A}$ & $\begin{array}{l}380.2\left[\mathrm{M}^{+}\right], \\
{[\mathrm{M}+1]}\end{array}$ & $\begin{array}{l}\text { 3.71-3.73 }\left(6 \mathrm{H}, \mathrm{s}, \text { for } \mathrm{OCH}_{3}\right), 5.13\left(2 \mathrm{H}, \mathrm{s} \text {, for } \mathrm{O}-\mathrm{CH}_{2}-\mathrm{CO}\right), 6.10-6.19(3 \mathrm{H}, \mathrm{m}, \text { for } \mathrm{Ar}-\mathrm{H}) \text {, } \\
7.47(1 \mathrm{H}, \mathrm{dd}, \text { for imidazole-H), } 7.82-7.84(2 \mathrm{H}, \mathrm{ddd}, \text { for } \mathrm{Ar}-\mathrm{H}), 7.88-7.90(1 \mathrm{H}, \mathrm{dd}, \text { for } \\
\text { imidazole-H), } 8.04-8.07(2 \mathrm{H}, \mathrm{ddd} \text {, for } \mathrm{Ar}-\mathrm{H}), 8.41(1 \mathrm{H}, \mathrm{s} \text {, for } \mathrm{N}=\mathrm{CH}), 8.93-8.95(1 \mathrm{H}, \mathrm{dd} \text {, } \\
\text { for imidazole-H), } 11.71(1 \mathrm{H}, \mathrm{s} \text {, for } \mathrm{NH}) \text {. }\end{array}$ \\
\hline 3B & $\begin{array}{ll}398.2\left[\mathrm{M}^{+}\right], & 399.2 \\
{[\mathrm{M}+1]} & \end{array}$ & $\begin{array}{l}\text { 3.70-3.72 }\left(6 \mathrm{H}, \mathrm{s}, \text { for } \mathrm{OCH}_{3}\right), 5.10\left(2 \mathrm{H}, \mathrm{s}, \text { for } \mathrm{O}-\mathrm{CH}_{2}-\mathrm{CO}\right), 6.08-6.18(3 \mathrm{H}, \mathrm{m}, \text { for } \mathrm{Ar}-\mathrm{H}) \text {, } \\
\text { 7.42-7.50 }(2 \mathrm{H}, \mathrm{m} \text {, for } \mathrm{Ar}-\mathrm{H}), 8.06-8.08(2 \mathrm{H}, \mathrm{m} \text {, for } \mathrm{Ar}-\mathrm{H}), 8.38(1 \mathrm{H}, \mathrm{s} \text {, for } \mathrm{N}=\mathrm{CH}), 11.67 \\
(1 \mathrm{H}, \mathrm{s} \text {, for } \mathrm{NH})\end{array}$ \\
\hline $3 C$ & $\begin{array}{l}365.3\left[\mathrm{M}^{+}\right], \quad 366.3 \\
{[\mathrm{M}+1]}\end{array}$ & $\begin{array}{l}3.74\left(6 \mathrm{H}, \mathrm{s} \text {, for } \mathrm{OCH}_{3}\right), 5.10\left(2 \mathrm{H}, \mathrm{s}, \text { for } \mathrm{O}-\mathrm{CH}_{2}-\mathrm{CO}\right), 6.26-6.28(3 \mathrm{H}, \mathrm{m}, \text { for } \mathrm{Ar}-\mathrm{H}), 7.55- \\
7.58(2 \mathrm{H}, \mathrm{d} \text {, for thiophene-H), } 8.07(1 \mathrm{H}, \mathrm{s} \text {, for } \mathrm{N}=\mathrm{CH}), 11.08(1 \mathrm{H}, \mathrm{s}, \text { for } \mathrm{NH})\end{array}$ \\
\hline 3D & $\begin{array}{ll}383.2\left[\mathrm{M}^{+}\right], & 384.2 \\
{[\mathrm{M}+1]} & \end{array}$ & $\begin{array}{l}1.88(4 \mathrm{H}, \mathrm{m}, \text { for pyrazolidine- } \mathrm{H}), 3.46-3.48(4 \mathrm{H}, \mathrm{m}, \text { for pyrazolidine- } \mathrm{H}), 3.70-3.72 \\
\left(6 \mathrm{H}, \mathrm{s}, \text { for } \mathrm{OCH}_{3}\right), 5.10\left(2 \mathrm{H}, \mathrm{s} \text {, for } \mathrm{O}-\mathrm{CH}_{2}-\mathrm{CO}\right), 6.20-6.30(3 \mathrm{H}, \mathrm{m} \text {, for } \mathrm{Ar}-\mathrm{H}), 6.71(2 \mathrm{H}, \\
\text { ddd, for } \mathrm{Ar}-\mathrm{H}), 7.38(2 \mathrm{H}, \mathrm{ddd}, \text { for } \mathrm{Ar}-\mathrm{H}), 8.05(1 \mathrm{H}, \mathrm{s} \text {, for } \mathrm{N}=\mathrm{CH}), 11.54(1 \mathrm{H}, \mathrm{s} \text {, for } \mathrm{NH})\end{array}$ \\
\hline $3 \mathbf{E}$ & $\begin{array}{l}318.3\left[\mathrm{M}^{+}\right], \quad 319.3 \\
{[\mathrm{M}+1]}\end{array}$ & $\begin{array}{l}3.59\left(3 \mathrm{H}, \mathrm{s}, \text { for } \mathrm{N}-\mathrm{CH}_{3}\right), 3.74-3.76\left(6 \mathrm{H}, \mathrm{s}, \text { for } \mathrm{OCH}_{3}\right), 5.10\left(2 \mathrm{H}, \mathrm{s}, \text { for } \mathrm{O}-\mathrm{CH}_{2}-\mathrm{CO}\right), 6.20- \\
6.23(3 \mathrm{H}, \mathrm{m} \text {, for } \mathrm{Ar}-\mathrm{H}), 7.30(1 \mathrm{H}, \mathrm{d} \text {, for imidazole- } \mathrm{H}), 7.40(1 \mathrm{H}, \mathrm{d} \text {, for imidazole- } \mathrm{H}) \\
7.78(1 \mathrm{H}, \mathrm{s} \text {, for } \mathrm{N}=\mathrm{CH}), 10.58(1 \mathrm{H}, \mathrm{s} \text {, for } \mathrm{NH})\end{array}$ \\
\hline $3 F$ & $\begin{array}{l}314.2\left[\mathrm{M}^{+}\right] \\
315.2[\mathrm{M}+1]\end{array}$ & $\begin{array}{l}\text { 3.74-3.76 }\left(6 \mathrm{H}, \mathrm{s} \text {, for } \mathrm{OCH}_{3}\right), 5.13\left(2 \mathrm{H}, \mathrm{s} \text {, for } \mathrm{O}-\mathrm{CH}_{2}-\mathrm{CO}\right), 6.26-6.32(3 \mathrm{H}, \mathrm{m}, \text { for } \mathrm{Ar}-\mathrm{H}) \text {, } \\
\text { 7.20-7.42 }(5 \mathrm{H}, \mathrm{m} \text {, for } \mathrm{Ar}-\mathrm{H}), 8.12(1 \mathrm{H}, \mathrm{s} \text {, for } \mathrm{N}=\mathrm{CH}), 10.88(1 \mathrm{H}, \mathrm{s} \text {, for } \mathrm{NH})\end{array}$ \\
\hline 3G & $\begin{array}{l}329.2\left[\mathrm{M}^{+}\right] \\
330.2[\mathrm{M}+1]\end{array}$ & $\begin{array}{l}\left.\text { 2.52-2.54 (3H, s, for pyridine- } \mathrm{CH}_{3}\right), 3.70-3.72\left(6 \mathrm{H}, \mathrm{s} \text {, for } \mathrm{OCH}_{3}\right), 5.12\left(2 \mathrm{H}, \mathrm{s} \text {, for } \mathrm{O}-\mathrm{CH}_{2}-\right. \\
\mathrm{CO}), 6.19-6.24(3 \mathrm{H}, \mathrm{m} \text {, for } \mathrm{Ar}-\mathrm{H}), 7.19-7.52(3 \mathrm{H}, \mathrm{m} \text {, for pyridine- } \mathrm{H}), 7.98(1 \mathrm{H}, \mathrm{s} \text {, for } \\
\mathrm{N}=\mathrm{CH}), 10.10(1 \mathrm{H}, \mathrm{s} \text {, for } \mathrm{NH})\end{array}$ \\
\hline $3 \mathrm{H}$ & $\begin{array}{l}382.2\left[\mathrm{M}^{+}\right], \quad 383.2 \\
{[\mathrm{M}+1]}\end{array}$ & $\begin{array}{l}3.74\left(6 \mathrm{H}, \mathrm{s} \text {, for } \mathrm{OCH}_{3}\right), 5.08\left(2 \mathrm{H}, \mathrm{s} \text {, for } \mathrm{O}-\mathrm{CH}_{2}-\mathrm{CO}\right), 6.20-6.22(3 \mathrm{H}, \mathrm{m}, \text { for } \mathrm{Ar}-\mathrm{H}), 7.41- \\
7.66(4 \mathrm{H}, \mathrm{m} \text {, for } \mathrm{Ar}-\mathrm{H}), 8.02(1 \mathrm{H}, \mathrm{s} \text {, for } \mathrm{N}=\mathrm{CH}), 10.58(1 \mathrm{H}, \mathrm{s} \text {, for } \mathrm{NH})\end{array}$ \\
\hline 3I & $\begin{array}{l}367.3\left[\mathrm{M}^{+}\right], \quad 368.3 \\
{[\mathrm{M}+1]}\end{array}$ & $\begin{array}{l}\text { 3.67-3.69 }\left(3 \mathrm{H}, \mathrm{s}, \text { for } \mathrm{N}-\mathrm{CH}_{3}\right), 3.72-3.74\left(6 \mathrm{H}, \mathrm{s} \text {, for } \mathrm{OCH}_{3}\right), 5.13\left(2 \mathrm{H}, \mathrm{s}, \text { for } \mathrm{O}-\mathrm{CH}_{2}-\mathrm{CO}\right) \\
6.20-6.23(3 \mathrm{H}, \mathrm{m}, \text { for } \mathrm{Ar}-\mathrm{H}), 7.21(1 \mathrm{H}, \mathrm{t} \text {, for pyrrole- } \mathrm{H}), 7.38-7.54(4 \mathrm{H}, \mathrm{m} \text {, for Ar-H), } \\
8.10(1 \mathrm{H}, \mathrm{s} \text {, for } \mathrm{N}=\mathrm{CH}), 11.28(1 \mathrm{H}, \mathrm{s} \text {, for } \mathrm{NH})\end{array}$ \\
\hline
\end{tabular}

Table 3: IR spectral data of compounds 3A-I

\begin{tabular}{|c|c|}
\hline Compd & IR $\left(\mathrm{cm}^{-1}\right)$ \\
\hline 3A & $\begin{array}{l}3113 \text { for } \mathrm{N}-\mathrm{H}, 2970 \text { for aliphatic } \mathrm{C}-\mathrm{H}, 1697 \text { for } \mathrm{C}=\mathrm{O} \text { of amide, } 1609 \text { for } \mathrm{C}=\mathrm{N} \text { of imines, } 1524 \text { for } \mathrm{N}-\mathrm{H} \text { bending } \\
\text { of amide, } 1261 \text { and } 1061 \text { for } \mathrm{C}-\mathrm{O} \text { of phenyl ether }\end{array}$ \\
\hline 3B & $\begin{array}{l}3198 \text { for } \mathrm{N}-\mathrm{H}, 3082 \text { for aromatic } \mathrm{C}-\mathrm{H}, 2970 \text { for aliphatic } \mathrm{C}-\mathrm{H}, 1693 \text { for } \mathrm{C}=\mathrm{O} \text { of amide, } 1605 \text { for } \mathrm{C}=\mathrm{N} \text { of imines, } \\
1508 \text { for } \mathrm{N}-\mathrm{H} \text { bending of amide, } 1261 \text { and } 1072 \text { for } \mathrm{C}-\mathrm{O} \text { of phenyl ether }\end{array}$ \\
\hline $3 \mathrm{C}$ & $\begin{array}{l}3113 \text { for } \mathrm{N}-\mathrm{H}, 3048 \text { for aromatic } \mathrm{C}-\mathrm{H}, 2963 \text { for aliphatic } \mathrm{C}-\mathrm{H}, 1686 \text { for } \mathrm{C}=\mathrm{O} \text { of amide, } 1612 \text { for } \mathrm{C}=\mathrm{N} \text { of imines, } \\
1528 \text { for } \mathrm{N}-\mathrm{H} \text { bending of amide, } 1281 \text { and } 1042 \text { for } \mathrm{C}-\mathrm{O} \text { of phenyl ether }\end{array}$ \\
\hline 3D & $\begin{array}{l}3202 \text { for } \mathrm{N}-\mathrm{H}, 3044 \text { for aromatic } \mathrm{C}-\mathrm{H}, 2967 \text { for aliphatic } \mathrm{C}-\mathrm{H}, 1674 \text { for } \mathrm{C}=\mathrm{O} \text { of amide, } 1609 \text { for } \mathrm{C}=\mathrm{N} \text { of imines, } \\
1524 \text { for } \mathrm{N}-\mathrm{H} \text { bending of amide, } 1246 \text { and } 1053 \text { for } \mathrm{C}-\mathrm{O} \text { of phenyl ether }\end{array}$ \\
\hline $3 \mathrm{E}$ & $\begin{array}{l}3132 \text { for } \mathrm{N}-\mathrm{H}, 3102 \text { for aromatic } \mathrm{C}-\mathrm{H}, 2994 \text { for aliphatic } \mathrm{C}-\mathrm{H}, 1701 \text { for } \mathrm{C}=\mathrm{O} \text { of amide, } 1609 \text { for } \mathrm{C}=\mathrm{N} \text { of imines, } \\
1524 \text { for } \mathrm{N}-\mathrm{H} \text { bending of amide, } 1285 \text { and } 1069 \text { for } \mathrm{C}-\mathrm{O} \text { of phenyl ether }\end{array}$ \\
\hline $3 \mathbf{F}$ & $\begin{array}{l}3190 \text { for } \mathrm{N}-\mathrm{H}, 3028 \text { for aromatic } \mathrm{C}-\mathrm{H}, 2916 \text { for aliphatic } \mathrm{C}-\mathrm{H}, 1686 \text { for } \mathrm{C}=\mathrm{O} \text { of amide, } 1597 \text { for } \mathrm{C}=\mathrm{N} \text { of imines, } \\
1555 \text { for } \mathrm{N}-\mathrm{H} \text { bending of amide, } 1292 \text { and } 1030 \text { for } \mathrm{C}-\mathrm{O} \text { of phenyl ether }\end{array}$ \\
\hline 3G & $\begin{array}{l}3059 \text { for } \mathrm{N}-\mathrm{H}, 2997 \text { for aromatic } \mathrm{C}-\mathrm{H}, 2947 \text { for aliphatic } \mathrm{C}-\mathrm{H}, 1717 \text { for } \mathrm{C}=\mathrm{O} \text { of amide, } 1624 \text { for } \mathrm{C}=\mathrm{N} \text { of imines, } \\
1539 \text { for } \mathrm{N}-\mathrm{H} \text { bending of amide, } 1250 \text { and } 1080 \text { for } \mathrm{C}-\mathrm{O} \text { of phenyl ether }\end{array}$ \\
\hline $3 \mathrm{H}$ & $\begin{array}{l}3202 \text { for } \mathrm{N}-\mathrm{H}, 2986 \text { for aromatic } \mathrm{C}-\mathrm{H}, 2963 \text { for aliphatic } \mathrm{C}-\mathrm{H}, 1701 \text { for } \mathrm{C}=\mathrm{O} \text { of amide, } 1605 \text { for } \mathrm{C}=\mathrm{N} \text { of imines, } \\
1516 \text { for } \mathrm{N}-\mathrm{H} \text { bending of amide, } 1242 \text { and } 1069 \text { for } \mathrm{C}-\mathrm{O} \text { of phenyl ether }\end{array}$ \\
\hline 3I & $\begin{array}{l}3102 \text { for } \mathrm{N}-\mathrm{H}, 3044 \text { for aromatic } \mathrm{C}-\mathrm{H}, 2943 \text { for aliphatic } \mathrm{C}-\mathrm{H}, 1690 \text { for } \mathrm{C}=\mathrm{O} \text { of amide, } 1620 \text { for } \mathrm{C}=\mathrm{N} \text { of imines, } \\
1524 \text { for } \mathrm{N}-\mathrm{H} \text { bending of amide, } 1254 \text { and } 1076 \text { for } \mathrm{C}-\mathrm{O} \text { of phenyl ether }\end{array}$ \\
\hline
\end{tabular}


Table 4: Antimicrobial activity of compounds 3A-I

\begin{tabular}{|c|c|c|c|}
\hline \multirow{2}{*}{ Compound number } & \multicolumn{3}{|c|}{ Zone of inhibition in mm } \\
\cline { 2 - 4 } & \multicolumn{2}{|c|}{ Antibacterial activity } & Antifungal activity \\
\cline { 2 - 4 } & S. aureus & C. coli & 10 \\
\hline 3A & 15 & 16 & 12 \\
\hline 3B & 18 & 19 & 17 \\
\hline 3C & 25 & 26 & 14 \\
\hline 3D & 21 & 22 & 15 \\
\hline 3E & 24 & 24 & 13 \\
\hline 3F & 20 & 18 & 12 \\
\hline 3G & 18 & 18 & 10 \\
\hline 3H & 16 & 16 & 15 \\
\hline 3I & 22 & 22 & --- \\
\hline Ampicillin & 25 & 24 & 17 \\
\hline Fluconazole & --- & -- & \\
\hline
\end{tabular}

\section{CONCLUSION:}

Antibiotic resistance is a serious and growing phenomenon in contemporary medicine and has emerged as one of the eminent public health concerns of the $21^{\text {st }}$ century, particularly as it pertains to pathogenic organisms. Hence in recent years, there has been a growing interest in researching and developing new antimicrobial agents from various sources to combat microbial resistance. Schiff bases (imines) possess wide variety of biological activities like antimicrobial, antitubercular, antimalarial and antiviral. Among various biological activities of several Schiff bases molecules synthesized in literature, the antimicrobial activity was found to be very prominent. It was also observed that Esters, Hydrazides and Imines can be synthesized from different moieties. From FTIR spectroscopy, it was concluded that the compounds were synthesized successfully as spectra includes different stretching bands for characteristics functional groups. The structures of Schiff bases were further confirmed by their ${ }^{1} \mathrm{H}-\mathrm{NMR}$ and mass spectroscopy. After carrying out the antimicrobial studies of newly synthesized compounds it was found that each compound $3 \mathrm{~A}$ to $3 \mathrm{I}$ possesses antibacterial and antifungal activities to certain extent. Among newly synthesized derivatives, compound 3C was found to be more potent than ampicillin when tested against the strains of Escherichia coli, whereas compounds 3E was found to be equipotent to ampicillin and fluconazole when tested on Staphylococcus aureus, Escherichia coli and Candida albicans. Schiff bases containing nitro thiophene nucleus has exhibited highest antimicrobial activity among all newly synthesized compounds.

\section{ACKNOWLEDGMENT}

The authors are thankful to Anuradha College of Pharmacy, Chikhli (M.S.), for providing necessary facilities.

\section{REFERENCES}

1. Tondan VK, Maurya HK, Mishra MN, Shukla PK. Design, synthesis and biological evaluation of novel nitrogen and sulfur containing hetero-1.4-naphthoquinones as potent antifungal and antibacterial agents. Eur J Med Chem. 2009; 44: 3130-7.

2. Dikid T, Jain SK, Sharma A, Kumar A, Narain JP. Emerging \& reemerging infections in India: An overview. Indian J Med Res. 2013; 138: 19-31.
3. Arulmurugan S, Kavitha PH, Venkatraman RP. Biological activities of Schiff base and its complexes: a review. Rasayan J Chem. 2010; 3(3): 385-410.

4. Schiff $\mathrm{H}$. Mitteilungen aus dem universitats laboratorium in Pisa: Eineneue reihe organischer basen. Justus Liebigs Ann Chem. 1864; 131: 118-119.

5. Dhar DN, Taploo CL. Schiff bases and their applications. J Sci Ind Res. 1982; 41: 501-506.

6. Przybylski P, Huczyński A, Pyta K, Brzezinski B, Bartl F. Biological properties of Schiff bases and azo derivatives of phenols. Curr Org Chem. 2009; 13: 124-148.

7. Bringmann G, Dreyer M, Faber JH, Dalsgaard PW, Staerk D, Jaroszewski JW. Ancistrotanzanine C and related 5,1'- and 7,3'coupled naphthylisoquinoline alkaloids from Ancistrocladus tanzaniensis. J Nat Prod. 2004; 67(5):743-748.

8. Salimon J, Salih N, Ibraheem H, Yousif E. Synthesis of 2-Nsalicylidene-5-(substituted)-1,3,4-thiadiazole as potential antimicrobial agents. Asian J Chem. 2010; 22(7):5289-5296.

9. Guo Z, Xing R, Liu S, Zhong Z, Ji X, Wang L. Antifungal properties of Schiff bases of chitosan, $\mathrm{N}$-substituted chitosan and quarternized chitosan. Carbohydr Res. 2007; 342(10):13291332.

10. Hussain Z, Yousif E, Ahmed A, Altaie A. Synthesis and characterization of Schiff's bases of sulfamethoxazole. Organic and Medicinal Chemistry Letters. 2014; 4:1.

11. Kumar A, Verma S, Mishra AK, Kumar S. Synthesis of some new Schiff bases of Pharmaceutical Interest. Ann Adv Chem. 2017; 1: 053-056.

12. Azab ME, Rizk SA, Mahmoud NF. Facile Synthesis, Characterization, and Antimicrobial Evaluation of Novel Heterocycles, Schiff Bases, and $N$-Nucleosides Bearing Phthalazine Moiety. Chem. Pharm. Bull. 2016; 64 (5) : 439-450.

13. Sharif HMA, Ahmed D, Mir H. Antimicrobial salicylaldehyde Schiff bases: Synthesis, characterization and evaluation. Pak. J. Pharm. Sci. 2015; 28(2): 449-455.

14. Fuloria NK, Fuloria S, Gupta R. Synthesis and Antimicrobial Profile of Newer Schiff Bases and Thiazolidinone Derivatives. International Scholarly and Scientific Research \& Innovation. 2014; 8(12).

15. Kumar S, Kumar P, Sati N. Synthesis and biological evaluation of Schiff bases and azetidinones of 1-naphthol. J Pharm Bioall Sci. 2012; 4:246-249.

16. Fuloria NK, Singh V, Shaharyar M, Ali M. Synthesis, characterization and biological studies of novel imines and azetidinones derivatives of Haloaryloxy moiety. Asian J. Chem. 2008; 20(6): 4891-4900.

17. Bauer AW, Kirby MM, Sherris JC, Turck M. Antibiotic susceptibility testing by a standardized single disc method. The American Journal of Clinical Pathology. 1966; 45(4): 493-496. 